\title{
Treatment and reuse of textile wastewater by overland flow
}

\begin{abstract}
This paper presents the findings of a laboratory scale study utilizing land treatment of textile wastewater after pretreatment by physico-chemical and biological processes. The textile industry is a growing industry in Malaysia. It contributes about $22 \%$ of the total volume of industrial wastewater generated in the country. The wastewater contains various types of pollutants from desizing, scouring, bleaching and dyeing processes. A single treatment process was found to be unsatisfactory for treating the wastewater. For example, the wastewater cannot be treated effectively by biological processes such as the activated sludge process because dyes may contain heavy metals such as chromium and lead that are toxic to microbes. Some are also refractory in nature. A combination of physico-chemical, biological and land treatment processes was attempted in this study. The treatment regime proposed would allow water reuse. The treated wastewater also complied with the regulatory effluent discharge requirements. Alum was added at a rate of $416 \mathrm{mg} / 1$ of wastewater as flocculant and lime at $213 \mathrm{mg} / 1$ as precipitant. Settling of floes was assisted by addition of polyelectrolyte at $11 \mathrm{mg} / 1$. An activated sludge process comprising a 301 aeration tank and a $20 \mathrm{~cm}$ ID conical settling tank was used in the study. Oxygen was supplied to the aeration tank via eight diffusers connected to air pumps. The process was maintained for 5 weeks to establish appropriate biological populations in the aeration tank. Sludge from a domestic wastewater treatment plant was used as the seeding material in the process. The biological system was operated with a loading rate of $0.9 \mathrm{~kg} \mathrm{COD} / \mathrm{m} 3$ and maintained at a $\mathrm{pH}$ between 7.0ï 8.5. The sludge recycles rate was $20 \%$ and nutrient addition was maintained at optimum level of BOD:N:P of 100:5:1. The nutrient addition was found to be necessary for the operation of the activated sludge system. Overland flow was effected by using two units of artificial grass beds of $62 \times 25 \times 5 \mathrm{~cm} 3$ each planted with Axonopus affinis and Panicum maximum. The beds were positioned at a $10^{\circ}$ angle and operated with alternate resting periods of about $5 \mathrm{~h}$ under direct sunlight before another application of pretreated wastewater was carried out. The rate of land application was $1.053 \mathrm{~cm} / \mathrm{d}$. Sample of effluent from the irrigation bed was taken over $12 \mathrm{~h}$ after the wastewater application. The raw wastewater has high BOD, COD, SS and $\mathrm{pH}$. The average $\mathrm{pH}$ level was 10.9 with average BOD, COD and SS values of 324, 2009 and $95 \mathrm{mg} / 1$, respectively. The combined pretreatment process could improve the quality of the wastewater, i.e., BOD, COD and SS reductions averaged at 48, 488 and $27 \mathrm{mg} / 1$, respectively. The BOD level was lower than the discharge limit for Class B rivers (i.e., $50 \mathrm{mg} / 1$ ) but the COD is higher than the regulatory limit of $100 \mathrm{mg} / 1$. Further reductions of BOD and COD to average values of 12 and $89 \mathrm{mg} / 1$, respectively, were achieved after the land treatment. The overall performance of the treatment system indicated that land irrigation is suitable for the treatment of textile wastewater. The treated effluent has a potential for reuse in agriculture and fisheries.
\end{abstract}

Keyword: Textile wastewater; Treatment; Overland flow; Water recycling 